\title{
Satisfaction and Motivation of General Physicians toward Their Career
}

\author{
Ameneh Barikani ${ }^{1}$, Maryam Javadi ${ }^{1}$, Aagil Mohammad ${ }^{2}$, Barikani Firooze ${ }^{3}$ \& Mojtaba Shahnazi $^{1}$ \\ ${ }^{1}$ Qazvin University of Medical Science, Qazvin, Iran \\ ${ }^{2}$ General Practitioner, Qazvin, Iran \\ ${ }^{3}$ Alborz Education Center, Tehran, Iran \\ Correspondence: Mojtaba Shahnazi, Qazvin University of Medical Science, Qazvin, Iran. E-mail: \\ shahnazi58@yahoo.com
}

Received: September 19, 2012 Accepted: October 8, 2012 Online Published: November 19, 2012

doi:10.5539/gjhs.v5n1p166 URL: http://dx.doi.org/10.5539/gjhs.v5n1p166

\begin{abstract}
Background: Human resource in health system especially in developing countries has main role in health promotion. Therefore their satisfaction and motivation are the key points in developing health system.
\end{abstract}

Objective: To determine the motivation and satisfaction of general physicians (GP) towards their career.

Methods: Using random sampling, 150 physicians were selected from comprehension commercial database list. Data were collected using a self-administered questionnaire that consisted of three sections; first demographic data, second work satisfaction and third questions toward biologic, dependent and growth motivation. Data were analyzed by SPSS version 16 with $\mathrm{P}<0.05$.

Results: From participants $64.7 \%$ of physicians were in age between $30-40$ years and $27.3 \%$ were men. Only $5.3 \%$ of physicians who were employed for over 10 years were satisfied from their career. Satisfaction of career among female and male physicians was $8 \%$ and $24 \%$ respectively. The item of job safety sensation in biologic motivation had maximum scale (4.1 \pm 0.89$)$. In dependent and growth motivations, value success sensation in job (4+-0.88) and make new skills and knowledge (4+-0.67) had maximum scale of mean. Relation of growth motivators with age $(\mathrm{P}<0.01)$, postgraduate duration $(\mathrm{P}<0.005)$ was significant. Dependent motivators had significant relation with age $(\mathrm{P}<0.04)$, postgraduate duration $(\mathrm{P}<0.01)$ and employment duration $(\mathrm{P}<0.002)$. Biological motivators had significant relation with sex $(\mathrm{P}<0.4)$ and satisfaction of work hours $(\mathrm{P}<0.007)$. Correlation of biological ( $r=0.44, \mathrm{P}<0.001)$ and growth $(\mathrm{r}=0.7, \mathrm{P}<0.001)$ motivators was significant.

Conclusion: Growth motivators score had higher ranking than other motivators. However, biological motivators especially job security and finance were also important and must be noticed from decision makers.

Keywords: satisfaction, motivation, general physicians

\section{Introduction}

Motivation is a process of arousing and sustaining goal-directed behavior induced by the expectation of satisfying individual needs. An employee's performance typically is influenced by motivation, ability and the work environment. Knowing how and why to motivate employees is an important managerial skill.

Change and the sustainability of change, depend on human qualities rather than on the quality of equipment or the quantity of money available. Improvements in health services require a motivated workforce to implement them and to ensure their survival during difficult times (Maclachlan \& Carr, 1993; Freiderike, 2009). The theories of motivation are generally categorized into two groups: content theories and process theories .Content theories focus primary on individual needs, attempting to explain the factors within a person that energize and stop behavior. They address the question "what factors motivate people?

Examples of content theories are Maslows hierarchy of needs theory (Scott- Myers, 1964). Alderfer's ERG theory (Alderfer, 1972), Herzberg's two-factor theory (Herzberg et al., 1959) and Mccelland's needs theory (McClelland, 1961).

Process theories focus on why and how of motivation investigating formally into the thinking process through 
which people choose one action versus another in the workplace (Ruthankoon \& Ogunlana, 2003).

Motivation has been a popular research topic for over 50 years .Performance and productivity of workers should still be important topics for management research in future, especially for knowledge workers who are valuable assets to institutions (Drucker, 1973). Motivation is a process that results from the dynamic interactions between individuals, their work environment and community or society (Franco et al. 2004; Bennett \& Kanfer, 2002).

In developing countries because of accessibility of health care is low, motivation of human resources is very important. In a study in Pakistan motivating factors were intrinsic and social cultural factors like serving people, respect and career growth (Malik et al., 2010).

The word motivation was derived from Latin term movers which means to move Definitions of motivation tend to center around now to provide something to a person to drive him (or her) to do something (Ruthankoon \& Ogunlana, 2003).

Productivity is defined as the efficient and effective use of resources with minimum waste and effort to achieve income. We live in a world that has limited resources. The health care leaders of health care organization are increasingly interested in ways to attract, retain and gain commitment from their employees. This interest is created in part because high turnover rates and the lack of commitment negatively affect the provision of care and the bottom live in their organizations. In a quality and cost conscious health care environment, health care managers need to find solutions for these difficult issues, solutions that are effective, efficient and sustainable.

According to World Health Organization(WHO) there is a worldwide estimation about shortage of 4.3 million health workers, primarily concentrated in south Asia followed by Africa (Malik et al., 2010; WHO, 2006). The burden of disease in these two regions is high. In other words Sub Saharan Africa and Southeast Asia together have 53\% of Global Burden of Disease, but 15\% of Worlds health care workforce (Raman, 2008; Malik et al., 2010). In Iran GP have responsibilities of management of health system and primary care.

The general practitioners in Iran currently face different changes in economical and job safety. GP employed in the area that are under constant pressure to do more with less, that lead to high levels of employee dissatisfaction. Physician satisfaction is a critical aspect of quality health care, allowing the development of a motivated workforce and committed to improving patient outcomes.

The study of motivation in developing countries, especially in Iran was low, therefore this study with aim assessment of motivation and satisfaction in GP was done.

\section{Material and Methods}

With a cross sectional study a random sample of 150 general physicians was drawn from a comprehension commercial database listing all 400 physicians actively practicing in Qazvin city a province of Iran Data were collected in 2008, with using a self-administered questionnaire that contain questions such as age, sex, duration of graduate and employee, income, second was job satisfactions of physical environment, opportunity for use of skills, income and work time and third part, 25 questions toward motivation base of Alderfer ERG (Existence, Relatedness, and Growth) motivation theory. Clayton Alderfer derived the ERG theory, which is an extension of Maslow's hierarchy of needs. Alderfer classified the needs into the categories: Existence, relatedness, and growth. According to Alderfer, the needs aren't in any order and any desire to fulfill, a need can be activated at any point in time. These results showed that, the lower level needs not requiring to be satisfied in order to satisfy a higher level needs. Alderfer's ERG theory can actually be utilized as a frustration-regression principle where an already satisfied lower level need can be "re-activated" when confronted with the impossibility of satisfying a higher level one.

Existence, related to person's physical needs such as food, clothing and shelter. Relatedness, relates to a person's interpersonal needs within his personal as well as professional settings. Growth relates to a person's needs of personal development (Alderfer, 1972). Internal consistency of questionnaire with Cronbachs Alpha was 86\%. Data were analyzed with $\mathrm{Chi}^{2}$ test and spearman correlation by SPSS version16 with $\mathrm{P}<0.05$.

\section{Results}

From total of participants, $27.3 \%$ were men. Postgraduate time was 5-10 year in $42.7 \%$ (Table 1). 
Table 1. Characteristics of physicians

\begin{tabular}{cll}
\hline \multicolumn{1}{l}{} & NO & $\%$ \\
\hline Age (year) & & \\
$-\quad<30$ & 32 & 21.3 \\
$-\quad 30-40$ & 97 & 64.7 \\
$-\quad>40$ & 21 & 14 \\
Postgraduate time (year) & & \\
$-\quad<5$ & 36 & 24 \\
$-\quad 5-10$ & 64 & 42.7 \\
$-\quad>10$ & 50 & 33.3 \\
Employment time (year) & & \\
$-\quad<5$ & 37 & 24.7 \\
$-\quad 5-10$ & 66 & 44 \\
$-\quad>10$ & 47 & 31.3 \\
Sex & & \\
$-\quad$ men & 41 & 27.3 \\
$-\quad$ women & 109 & 64.7 \\
\hline
\end{tabular}

26.7\% of them had high satisfaction toward their career (Table 2).

Table 2. Satisfaction of physicians toward their career

\begin{tabular}{|c|c|c|c|c|c|}
\hline & & Yes & SOMEDEAL & NO & $\mathrm{P}$ \\
\hline \multicolumn{6}{|c|}{ Income } \\
\hline- & high & 6 & 0.7 & 0 & \multirow[t]{3}{*}{0.000} \\
\hline - & moderate & 11.3 & 12.7 & 4 & \\
\hline- & low & 14.7 & 26 & 24.7 & \\
\hline \multicolumn{6}{|c|}{ Hours of work } \\
\hline- & very & 5.3 & 1.3 & 0.7 & \multirow[t]{3}{*}{0.000} \\
\hline- & moderate & 16 & 10.7 & 1.3 & \\
\hline - & few & 10.7 & 27.3 & 26.7 & \\
\hline \multicolumn{6}{|c|}{ Knowledge about profession } \\
\hline- & yes & 7.3 & 8 & 1.3 & \multirow[t]{3}{*}{0.000} \\
\hline- & SOMEDEAL & 15.3 & 20.7 & 6.7 & \\
\hline- & no & 9.3 & 10.7 & 20.7 & \\
\hline \multicolumn{6}{|c|}{ Employment time } \\
\hline- & $<5$ & 13.3 & 8.7 & 2.7 & \multirow[t]{3}{*}{0.003} \\
\hline - & 5-10 & 13.3 & 15.3 & 16.3 & \\
\hline- & $>10$ & 5.3 & 15.3 & 10.7 & \\
\hline \multicolumn{6}{|c|}{ Postgraduate time } \\
\hline - & $<5$ & 13.3 & 8 & 2.7 & \multirow[t]{3}{*}{0.006} \\
\hline- & $5-10$ & 11.3 & 16 & 15.3 & \\
\hline- & $>10$ & 7.3 & 15.3 & 10.7 & \\
\hline \multicolumn{6}{|l|}{ Sex } \\
\hline- & female & 8 & 16 & 3.3 & \multirow[t]{2}{*}{0.005} \\
\hline- & male & 24 & 23.3 & 25.3 & \\
\hline
\end{tabular}


Age (year)

$\begin{array}{lllll}- & <30 & 12.7 & 6.7 & 2 \\ - & 30-40 & 14 & 28.7 & 22 \\ - & >40 & 5.3 & 4 & 4.7\end{array}$

Physical environment

$\begin{array}{llllll}- & \text { Good } & 6 & 1.3 & 0.7 & 0.000 \\ - & \text { not bad } & 18 & 14.7 & 6 & \\ - & \text { bad } & 8 & 23.3 & 22 & \end{array}$

Opportunity for use of skill

$\begin{array}{lllll}- & \text { yes } & 6 & 2 & 3.3 \\ - & \text { accessional } & 14.7 & 25.3 & 6.7 \\ - & \text { no } & 11.3 & 12 & 15.7\end{array}$

Job safety sensation in biological motivation with score of 4.1+-0.89, value success sensation in job in dependent motivation with score of $4+-0.88$ and new skills and knowledge in growth motivation with score of $4+-0.67$ had highest score (Table 3 )

Table 3. Mean score of motivation in physicians

\begin{tabular}{|c|c|c|c|}
\hline & & Mean & SD \\
\hline \multicolumn{4}{|c|}{ Biological motivation } \\
\hline- & job safety sensation & 4.1 & 0.89 \\
\hline- & merit available & 3.7 & 0.99 \\
\hline- & effect of job on private life & 3.7 & 1.01 \\
\hline- & income & 3.9 & 0.89 \\
\hline- & convenience availability appropriate & 3.8 & 0.77 \\
\hline- & workplace room appropriate & 3.9 & 0.75 \\
\hline \multicolumn{4}{|c|}{ Dependent motivation } \\
\hline- & value success sensation in job & 4 & 0.88 \\
\hline- & high level job and population notice & 3.7 & 0.81 \\
\hline- & to put in practice & 3.6 & 0.8 \\
\hline- & independence judgment & 3.6 & 1.05 \\
\hline- & good relationship with others & 4 & 0.66 \\
\hline- & to draw patient confidence & 4.1 & 0.75 \\
\hline- & team work possibility & 3.3 & 0.98 \\
\hline- & good relationship with colleagues & 3.5 & 0.93 \\
\hline- & Belonging sensation to population & 3.7 & 0.93 \\
\hline- & patient appreciation & 3.5 & 0.89 \\
\hline- & self-respect sensation & 3.3 & 1.7 \\
\hline \multicolumn{4}{|c|}{ Growth motivation } \\
\hline- & opportunity for self-improvement & 3.9 & 0.83 \\
\hline- & opportunity for receive continual education & 3.7 & 0.83 \\
\hline- & receive colleagues experiment & 3.4 & 0.8 \\
\hline- & new skills and knowledge & 4 & 0.67 \\
\hline
\end{tabular}

In this study score of biological motivators in men was higher than women $(\mathrm{P}=0.04)$. 
Table 4. Mean score of three motivations with character of physicians

\begin{tabular}{|c|c|c|c|c|}
\hline & & Biological & Dependent & Growth \\
\hline \multicolumn{5}{|c|}{ Age (year) } \\
\hline - & $<30$ & $4 \pm 0.49$ & $3.8 \pm 0.31$ & $4 \pm 0.29$ \\
\hline- & $30-40$ & $3.7 \pm 0.61$ & $3.6 \pm 0.61$ & $3.8 \pm 0.53$ \\
\hline- & $>40$ & $3.8 \pm 0.66$ & $3.9 \pm 0.4$ & $4.1 \pm 0.41$ \\
\hline$P$ & & 0.1 & 0.04 & 0.01 \\
\hline \multicolumn{5}{|l|}{ Sex } \\
\hline- & female & $3.6 \pm 0.6$ & $3.6 \pm 0.6$ & $3.8 \pm 0.5$ \\
\hline- & male & $3.9 \pm 0.58$ & $3.7 \pm 0.5$ & $3.9 \pm 0.48$ \\
\hline $\mathrm{P}$ & & 0.04 & 0.1 & 0.1 \\
\hline \multicolumn{5}{|c|}{ Postgraduate duration (year) } \\
\hline- & $<5$ & $3.9 \pm 0.56$ & $3.8 \pm 0.31$ & $4 \pm 0.33$ \\
\hline- & $5-10$ & $3.7 \pm 0.66$ & $3.8 \pm 0.52$ & $3.8 \pm 0.55$ \\
\hline- & $>10$ & $3.8 \pm 0.53$ & $3.7 \pm 0.53$ & $3.9 \pm 0.48$ \\
\hline $\mathrm{P}$ & & 0.2 & 0.01 & 0.05 \\
\hline \multicolumn{5}{|c|}{ Employment duration (year) } \\
\hline- & $<5$ & $3.9 \pm 0.56$ & $3.8 \pm 0.4$ & $4 \pm 0.37$ \\
\hline- & $5-10$ & $3.8 \pm 0.66$ & $3.8 \pm 0.5$ & $3.6 \pm 0.54$ \\
\hline- & $>10$ & $3.7 \pm 0.52$ & $3.7 \pm 0.53$ & $3.9 \pm 0.48$ \\
\hline $\mathrm{P}$ & & 0.3 & 0.02 & 0.1 \\
\hline \multicolumn{5}{|c|}{ Satisfaction of income } \\
\hline- & yes & $3.5 \pm 0.47$ & $4 \pm 0.43$ & $4.1 \pm 0.42$ \\
\hline- & no & $3.9 \pm 0.56$ & $3.6 \pm 0.55$ & $3.9 \pm 0.46$ \\
\hline $\mathrm{P}$ & & 0.5 & 0.2 & 0.7 \\
\hline \multicolumn{5}{|c|}{ Satisfaction of work hours } \\
\hline- & yes & $3.9 \pm 0.57$ & $4.2 \pm 0.58$ & $4.3 \pm 0.44$ \\
\hline- & no & $3.7 \pm 0.62$ & $3.6 \pm 0.52$ & $3.8 \pm 0.51$ \\
\hline $\mathrm{P}$ & & 0.007 & 0.09 & 0.2 \\
\hline
\end{tabular}

High level needs in physicians very important in 38.7\%.

Table 5. Percent of motivation important in view of physicians $(n=150)$

\begin{tabular}{llll}
\hline & Very & Moderate & Low \\
\hline Biological & 29.3 & 56.7 & 14 \\
Dependent & 29.3 & 56.7 & 14 \\
Growth & 48 & 48.7 & 3.3 \\
\hline
\end{tabular}

\section{Discussions}

Human resource in health system has central role in improving health, motivation and satisfaction. In this study aspects of biological motivation was important. Biological need was one of the basic needs that is neglected but could effect on motivation. Among different aspect of biological motivators, job security is most important. If physicians have job security, then other aspects of biological motivators will be influenced by job security. Unemployment in medical graduates in many studies in Iran was 12.2\% (Mirkamali, 1990; Dehghani, 2007). Most of physicians especially young physicians have concern about future career and job security. According to long duration of education in this profession, physicians have high expectations and job security is the minimum request of them.

Organizational factors particularly in current job settings could be the most de motivator, a finding that echoed in other studies (Reid, 2004; Chikanda, 2005; Ssengooba et al., 2007; Malik et al., 2010). Although money is not only motivator, but is important along with others motivators. If physicians have financial problems may have a 
tendency to un medical activities in addition to decrease motivation. In a study in Iran, 15\% of GP work in un medical profession and 5\% were abroad. In this study different aspects of dependent motivator were important, among these motivators, value success sensation was most important. This sensation can guide individuals to value objects. In other word disappointment sensation and unimprovement in the job is a strong motivator. Certain intrinsic and socio-cultural factors such as respecting people and opportunities for career growth are important motivators. Recognition by employers and communities and draw their net ice and good relationship with them and colleagues was important (Franco et al., 2004; Agyepong et al., 2004; Dieleman, Toonen, Toure \& Martineau, 2006; Manongi, Marchant \& Bygbjerg, 2006; Ssengooba et al., 2007).

In compare growth motivators was more important than others. Individuals that practice as physician have high level expectations. In related their job, as if biological and dependent motivators have intermediate role. Decision makers must be notice this fact for improving function of health system. According to Alderfer theory an individuals can move from low levels of needs to high on the condition that they struggle to meet their needs, in this way decision makers must notice to high level needs of their employers (Moghimi, 2006). In a study in Vietnam, most motivators were managers and colleagues gratitude, job security, sufficient income and education (Dieleman, 2003). Lack of opportunities for higher specialization is one of important de motivator as seen in other studies (Malik et al., 2010). Tendency to specialization could be refer to financial and job security problems. Tend to continue of education after duration of general practitioner (GP) in Iranian physicians is very high (Nejat et al., 2007; Buddeberg-Fischer et al., 2006; Lambert et al., 2006). This fact must be noticed by decision makers. Satisfaction of hours of work was $7.3 \%$ in our study, this results was not similar to Al-Eisa study (Ibrahim, Manal \& Huda, 2005; Catherine M Joyce et al., 2011). Barnes said that hours of work is one factor that can affect internal satisfaction, directly (Barnes, 1998). Dwell believed that long duration hours of work is one of unsatisfaction factors (Dowell, Hamilton, \& McLeod, 2000). In our study 16.7\% 0f physicians had sufficient knowledge about their profession.

These problems refer to insufficient information toward medical profession at the time of entering to university to start medical education. These students have not any knowledge about their responsibilities and problem of their profession that was not similar to Al-Eisa study (Ibrahim, Manal \& Huda, 2005). In our study satisfaction in young physicians was higher than old, that was not similar to other studies (Ibrahim, Manal \& Huda, 2005; Haas et al., 1998). Young physicians often have not enough information about their responsibility and problems that may be faced with it. Our results showed that satisfaction of male physicians was higher than female, that was not similar to other studies (Okerlund, Jacson, \& Parsons, 1994; McMurray et al., 2000; Ibrahim, Manal \& Huda, 2005) and similar to Frank and Malik study (Frank, McMurray, Linzer, \& Elon, 1999; Pas et al., 2008; Malik et al., 2010). Household responsibilities and restriction for working in anywhere and region can affect their satisfaction and motivation. Our study showed that employment time have affect on satisfaction and follow motivation. Physicians that their employment time was higher than 10 years were more satisfied, that was not similar to Al-Eisa study (Ibrahim et al. 2005, Manal \& Huda, 2005). Physicians soon after postgraduate have not job stability, because want to participate in specialty exam or spend their legal duty in health system (Tarh). In our study relation of growth motivation with satisfaction was significant $(\mathrm{P}<0.01)$ similar to Okerlund study (Okerlund, Jacson \& Parsons, 1994). Also high level motivation in workplace can drive individuals' attention from low levels needs to high but managers must notice to three level of motivation, because significant relation was seen between different levels of motivation.

Motivation does not remain static and is dependent on many continually changing factors in a community like Iran that younger physicians faced to economic problems.

This study was first of its hind in the region to investigate physician's motivation. The results of this study showed that if biological motivators were important, but most of physicians have growth needs that must be noticed by decision makers.

\section{Acknowledgement}

This paper is result of the M.D. thesis no. 728 in Qazvin University of Medical Sciences. The present study was ethically confirmed by committee of research department of Qazvin Medical School. We deeply thank the staff of research department of Qazvin Medical School for their support. 


\section{References}

Agyepong, I. A., Anafi, P., Asiamah, E., Ansah, E., Ashon, D., \& Narh-Dometey, C. (2004). Health worker (internal customer) satisfaction and motivation in the public sector in Ghana. Int $J$ Health Plann Manage, 19, 319-336. http://dx.doi.org/10.1002/hpm.770

Alderfer, C. P. (1972). Existence, relatedness and growth. Free press, New York.

Al-Eisa, I. S., Al-Mutar, M. S., \& Al-Abduljalil, H. K. (2005). Job satisfaction of primary health care physicians at capital health region. Kuwait. MEJFM, 3(3).

Barmes, D. S. (1998). Job satisfaction and the rehabilitation professional. 14: 1-2.

Buddeberg-Fischer, B., Klaghofer, R., Stamm, M., Marty, F., Dreiding, P., Zoller, M., et al. (2006). Primary Care in Switzerland - no longer attractive for young physicians? Swiss Med Wkly, 1(6), 416-424.

Chikanda, A. (2005). Nurse migration from Zimbabwe: analysis of recent trends and impacts. Nurs Inq, 12(3), 162-174. http://dx.doi.org/10.1111/j.1440-1800.2005.00273.x

Dehghani, M. R., Kamyabi, A., Haghdost, A. A., Roholamini, A., Hoseininejad, Z., \& Mosapoor, N. (2007). Career of medical students after graduate in Medical University of Kerman. Journal of EDC, 4(2), 67-77.

Dieleman, M., Cuong, P. V., Anh, L. V., \& Martineau, T. (2003). Identifying factors for job motivation of rural health workers in North Vietnam. Hum Resour Health, 1(1), 10. http://dx.doi.org/10.1186/1478-4491-1-10

Dieleman, M., Toonen, J., Toure, H., \& Martineau, T. (2006). The match between motivation and performance management of health sector workers in Mali. Hum Resour Health, 4, 2. http://dx.doi.org/10.1186/1478-4491-4-2

Dowell, A. C., Hamilton, S., \& McLeod, D. K. (2000). Job satisfaction, psychological morbidity and job stress among New Zealand general practitioners. N Z Med J, 113(1113), 269-272.

Drucker, P. F. (1973). Management: Tasks, responsibilities, and practices. New York: Harper and Row

Franco, L. M., Bennett, S., \& Kanfer, R. (2002). Health sector reform and public sector health worker motivation: a conceptual framework. Soc Sci Med, 54(8), 1255-1266. http://dx.doi.org/10.1016/S0277-9536(01)00094-6

Franco, L. M., Bennett, S., Kanfer, R., \& Stubblebine, P. (2004). Determinants and consequences of health worker motivation in hospitals in Jordan and Georgia. Soc Sci Med, 58(2), 343-355. http://dx.doi.org/10.1016/S0277-9536(03)00203-X

Frank, E., McMurray, J. E., Linzer, M., \& Elon, L. (1999). Career satisfaction of US women physicians: results from the Women Physicians' Health Study. Society of General Internal Medicine Career Satisfaction Study Group. Arch Intern Med, 159(13), 1417-1426. http://dx.doi.org/10.1001/archinte.159.13.1417

Freiderike, P. (2009). Health worker motivation and the role of performance based finance system in Africa: A Qualitative Study on Health Worker Motivation and the Rwanda. No8- 96

Haas, J. S., Cleary, P. D., Puopolo, A. L., Burstin, H. R., Cook, E. F., \& Brennan, T. A. (1998). Differences in the professional satisfaction of general internists in academically affiliated practices in the greater-Boston area. Ambulatory Medicine Quality Improvement Project Investigators. J Gen Intern Med, 13(2), 127-130. http://dx.doi.org/10.1046/j.1525-1497.1998.00030.x

Herzberg, F., Mausner, B., \& Shyderman, B. B. (1959). The morivation to work. John wiley and sons, New York.

Joyce, C. M., Schurer, S., Scott, A., Humphreys, J., \& Kalb, G. (2011). Australian doctors' satisfaction with their work: results from the MABEL longitudinal survey of doctors. MJA, 194, 30-33

Lambert, T. J., Goldacre, M. J., \& Turner, G. (2006). Career choices of United Kingdom medical graduates of 2 2: questionnaire survey. Med Educ, 4, 14-21.

Maclachlan, M., \& Carr, S. (1993). Demotirating the doctors: The double demotivation hypothesis in the health sevices of less-developed countries. J Management Med, 7(6), 6-10.

Malik, A. A., Yamamoto, S. S., Souares, A., Malik, Z., \& Sauerborn, R. (2010). Motivational determinants among physicians in Lahore, Pakistan. BMC Health Serv Res, 10, 201. http://dx.doi.org/10.1186/1472-6963-10-201

Manongi, R. N., Marchant, T. C., \& Bygbjerg, I. C. (2006). Improving motivation among primary health care workers in Tanzania: a health worker perspective. Hum Resour Health, 4, 6. http://dx.doi.org/10.1186/1478-4491-4-6 
McClelland, D. C. (1961). The Achieving Society. Princeton, NJ: Van Nostrand.

McMurray, J. E., Linzer, M., Konrad, T. R., Douglas, J., Shugerman, R., \& Nelson, K. (2000). The Work Lives of Women Physicians. J Gen Intern Med, 15(6), 372-380.

Mirkamali, M. (1990). Analysis of postgraduate students of Universities skills. Research and Planning Bulletin, 1(4), 14-37.

Moghimi, S. M. (2006). Research approach to management organization. Termeh publisher, Tehran.

Nejat, S., Emami Razavi, H., Rashidian, A., Yazdani, S. H., \& Majdzadeh, R. (2007). Attitudes of medical students toward cause of selection of medicine and Knowing about future career in Medical University of Tehran. Journal of EDC, 3(1), 1-10(in Persian).

Okerlund, V. W., Jacson, P. B., \& Parsons, R. J. (1994). Factors affecting recruitment of physical therapy, 74, 177-184.

Pas, B. R., Lagro-Janssen, A. L., Doorewaard, J. A., Eisinga, R. N., \& Peters, C. P. (2008). Gender differences in career motivation: female doctors' ambitions benefit from family friendly work environment. Ned Tijdschr Geneeskd, 152(40), 2172-6.

Raman, V. V. (2008). The healthcare workforce shortage - a new pandemic. 2008.

Reid, S. (2004). Monitoring the effect of the new rural allowance for health professionals. Research Project Report, 1-7.

Ruthankoon, R., \& Ogunlana, S. O. (2003). Testing herzberg's two-factor theary in the thai construction industry. Eng Construct Architect Manag, 10(5), ABI/WFORM Global, 333.

Scott Myers, M. (1964). Who are your motivated workers? Harvard business review, 42(4110), 73-88.

Ssengooba, F., Rahman, S. A., Hongoro, C., Rutebemberwa, E., Mustafa, A., Kielmann, T., \& McPake, B. (2007). Health sector reforms and human resources for health in Uganda and Bangladesh: mechanisms of effect. Hum Resour Health, 5, 3. http://dx.doi.org/10.1186/1478-4491-5-3

WHO. (2006). Working Together for Health. The World Health Report 2006.Geneva. 